\title{
Peculiarities of neuropathic pain in children
}

\author{
Peculiaridades da dor neuropática na criança \\ Sandra Caíres Serrano', Silvia Maria de Macedo Barbosa², Emanuelle Jardim Queiroz ${ }^{3}$, Fabiana Gomes de Campos ${ }^{1}$, Ana Paula de Souza Vieira Santos ${ }^{4}$
}

DOI 10.5935/1806-0013.20160061

\section{ABSTRACT}

BACKGROUND AND OBJECTIVES: In spite of its importance, neuropathic pain is underestimated and undertreated in childhood. Although many conditions causing neuropathic pain in adults are uncommon during childhood, most therapeutic strategies effective for adults were extrapolated for the pediatric population. This study aimed at bringing to light peculiarities of neuropathic pain in children, which shall contribute for its better recognition in childhood and adolescence.

CONTENTS: Pubmed, Scielo and Lilacs databases were queried to identify studies and literature reviews on neuropathic pain during childhood and adolescence. CONCLUSION: Neuropathic pain treatment in childhood and adolescence should be multimodal, including pharmacological treatment, rehabilitation and psychological support. Rehabilitation, physiotherapy, occupational therapy and integrative therapies should be part of the integral treatment in childhood and adolescence and vary in a case-by-case basis.

Keywords: Adolescence, Childhood, Children, Integrative therapy, Neuropathic pain, Occupational therapy, Pharmacology, Rehabilitation.

\section{RESUMO}

JUSTIFICATIVA E OBJETIVOS: Apesar de sua importância a dor neuropática é subestimada e subtratada na infância. Embora muitas das condiçóes que causem dor neuropática no adulto sejam raras na infância; grande parte das estratégias terapêuticas que demonstraram ser eficazes em adultos foi extrapolada para uso na populaçấo pediátrica. O objetivo deste estudo artigo foi trazer à luz peculiaridades da dor neuropática na criança, o que contribuirá para seu melhor reconhecimento na infância e adolescência.

CONTEÚDO: Foram realizadas buscas nos bancos de dados Pubmed, Scielo e Lilacs, identificando-se estudos e revisōes da literatura sobre dor neuropática na infância e adolescência.

CONCLUSÁO: $O$ tratamento da dor neuropática na infância e adolescência deve ser multimodal, incluindo tratamento farmacológico, reabilitaçáo e suporte psicológico. Reabilitação, fisioterapia, terapia ocupacional e terapias integrativas devem fazer parte do tratamento integral na infância e adolescência, e variam conforme as necessidades em cada caso.

Descritores: Adolescência, Criança, Dor neuropática, Farmacologia, Infância, Reabilitação, Terapia integrativa, Terapia ocupacional.

\section{INTRODUCTION}

Chronic pain in childhood is an underestimated reality in Brazi. In the United States, it has mean prevalence of $11 \%$ to $38 \%$, with $3 \%$ to $5 \%$ of children with significant pain-related incapacity and annual estimated cost of 19,500 billion dollars ${ }^{1}$.

1. AC Camargo Câncer Center, Departamento de Terapia Antálgica, Neurocirurgia Funcional e Cuidados Paliativos. São Paulo, SP, Brasil.

2. Faculdade de Medicina da Universidade de Sáo Paulo, Hospital das Clínicas, Unidade de Dor e Cuidados Paliativos do Instituto da Criança. São Paulo, SP, Brasil.

3. Associaçáo Paulista de Medicina Ama City Jaraguá, Departamento de Pneumologia Pediátrica, Campinas, SP, Brasil.

4. Santa Casa de São Paulo, Unidade de Tratamento da Dor e Cuidados Paliativos Infantil. São Paulo, SP. Brasil.

Conflict of interests: none - Sponsoring sources: none.

Correspondence to:

Sandra Caíres Serrano.

Av. Bosque da Saúde, 546, apto 202 - Bosque da Saúde.

04142-081. Sáo Paulo, SP. Brasil.

E-mail: scserrano@uol.com.br

(C) Sociedade Brasileira para o Estudo da Dor
The International Association for the Study of Pain (IASP) defines neuropathic pain (NP) as "pain started or induced by primary injury or disorder of the nervous system (central, peripheral or autonomous)" ${ }^{2}$. More recently, IASP's Neuropathic Pain Special Interest Group (NeuPSIG) has redefined $\mathrm{NP}$ as being "pain as direct result of injury or disorder affecting the somatosensory system" 3 . However, the definition itself stresses that not all somatosensory system injuries lead to NP. Its diagnosis is essentially clinic. Specific complementary exams are almost always related to specific investigation situations, being seldom used in the clinical practice ${ }^{3}$.

Pain is a multidimensional phenomenon involving physical, sensory and emotional aspects, within the biopsychosocial model. Incapacity to determine the underlying cause should not be reason to conclude that pain is not real. A significant number of children and adolescents with chronic pain have high levels of fear with regard to pain, fear which is associated to a high level of incapacity, depressive symptoms and school impairment ${ }^{1}$. In NP, decreased fear is associated to better physical and psychological functioning, while high level of initial fear of pain is a risk factor for lower treatment response capacity ${ }^{1}$. Emotional responses may affect pain evaluation in general and it is important to know what children and adolescents think about themselves and their pain.

In the last 30 years, studies related to pain in childhood are bringing further knowledge on how nociceptive system in development responds to tissue injury and how children perceive pain (acute and chronic) in different age groups, contributing for the search of strategies (pharmacological and non-pharmacological) for pain relief ${ }^{4}$. As it happens with adults, children may suffer different types of pain: acute pain related to disease or trauma, recurrent pain episodes (as for example in headache, epigastric pain, etc.), limb pain unrelated to disease, or chronic pain due to injury, disease, psychologic factors, or even unknown etiology.

The prevalence of some types of pain is different in adults and children. In general, recurrent pain syndromes (abdominal pain, headache, phantom pain or growing pains) are more common problems for children ${ }^{4}$. The fact that children in non-verbal phase and/or with cognitive deficits are unable to express their pain makes difficult its recognition, reason why children's pain is underdiagnosed and inadequately treated ${ }^{5}$. In addition, there are few quality studies on the nature, etiology, diagnosis, prognosis and treatment of major NP causes in the pediatric population, since most part of currently available literature consists in clinical trial reports or studies of small series, without control group and with short follow up period ${ }^{6}$.

Although NP semiology in childhood might be comparable to that of adults, its etiology is often different, with the worsening factor that therapeutic options are more limited, even due to the lack of studies involving pediatric patients ${ }^{5}$. Another difficulty of diagnosing NP in the pediatric population is the lack of screening questionnaires and validated tools for this population. In this context, it is recommended the use of Wong-Baker faces scale, validated for children as from 3 years of age ${ }^{5}$. Pain should be recorded as the fifth vital sign, always systematically, and the scale to be used depends on age and presence or not of cognitive impairment ${ }^{7}$.

NP might be considered a clinical entity with common pattern of signs and symptoms, frequently with similar management regardless of the underlying cause. In NP, the coexistence of negative symptoms is identified, which reflects loss of somatosensory system function, and of positive symptoms, which indicate somatosensory system function gain ${ }^{5}$. These symptoms may be classified as spontaneous, evoked (triggered by mechanical, chemical or thermal stimulation such as allodynia or hyperalgesia), and symptoms which are more frequently spontaneous, but which may also be evoked, as paresthesias and dysesthesias 5 . In addition to these symptoms, motor signs such as spasms, dystonia, fasciculations, muscle weakness and atrophy, and disautonomic signs, such as cyanosis, erythema, edema, increased sweating and poor capillary filling might be present in $\mathrm{NP}^{5}$.

Typical NP features include paroxysmal or spontaneous pain. Frequently 
used descriptors to characterize NP include numbness, burning, tingling, pricking, smarting, hot, compression, pressing, shooting pain, electric shock, electric discharge and painful cold sensation ${ }^{5}$.

According to van Dijk et al., chronic pain in children is reported in up to $6 \%$ of children and adolescents, but NP proportion is not clear ${ }^{8}$. Conditions associated to NP in children are different from those found in adults, even because conditions often associated to NP in adults have much lower incidence in children and adolescents ${ }^{9}$

In the last 20 years, there has been further recognition of some neuropathic conditions in children, such as complex regional pain syndrome (CRPS) (especially type I), phantom limb pain, spinal cord injuries, cancer and its treatment, traumas, postoperative NP, autoimmune and degenerative neuropathies and sickle cell disease. In addition to these conditions, some NPrelated syndromes are more uncommon and characteristic of the pediatric population, such as metabolic diseases, toxic neuropathies (lead, mercury), mitochondrial diseases and erythromelalgia 5 .

Further neuroplasticity in children may be responsible for differences between children and adult NP, and it seems to allow better function recovery, thus lower incidence of NP in adulthood 5 .

Understanding NP peculiarities in childhood is a challenge. Experimental studies in animal models help understanding the relationship of NP pathophysiology as a function of age. Animal models with peripheral traumatic neurological injuries have shown decreased sensitivity to NP when the injury happens in younger ages ${ }^{10}$. The incidence of NP related to perinatal brachial plexus injury is extremely low, as opposed to musculoskeletal nociceptive pain or temporary reinnervation pain. The incidence of NP is also low in other traumatic brachial plexus injuries in older children ${ }^{5}$. Younger children have better sensory recovery and lower possibility of developing chronic NP as compared to adults, according to Atherton et al. ${ }^{11}$.

Spinal cord injury in children is uncommon, but NP might be present and recovery in younger children seems to be better than in older ages ${ }^{6}$. Tumor compression may induce tissue and nerve injury leading to NP, specially in cases of brachial plexus or sciatic nerve compression by unresectable solid tumors ${ }^{5,6}$.

Children with human immunodefficiency vírus infection (HIV) may have peripheral neuropathy. Although pain has been referred in a larger number of children with HIV infection as compared to the control group, NP was not specifically identified. The incidence of pain in children with HIV infection also seems to be lower as compared to adults ${ }^{12}$.

The incidence of postherpetic neuralgia is less common in children as compared to adults, especially affecting immunosuppressed children ${ }^{13}$.

Diabetes mellitus is common cause of peripheral neuropathy and NP in adults, although the same is not true for children. Sensory changes, especially subtle differences in nociceptive thresholds may be detected in children even in the absence of NP symptoms ${ }^{5}$. Painful diabetic neuropathy is seldom reported before 14 years of age ${ }^{13}$, but sensory changes were detected in children before pain onset ${ }^{14}$.

Persistent postoperative NP is described in pediatric population, but its incidence is unknown ${ }^{5}$. A retrospective crossover study with children and adolescents, carried out by Chou, Chan $\&$ Chalkiadis $^{15}$ aiming at determining chronic post-thoracotomy pain prevalence (defined as persistent or recurrent incisional for at least 2 months after thoracotomy), has shown low prevalence of post-thoracotomy pain in childhood and adolescence as opposed to what happens with adults.

Phantom limb pain has neuropathic characteristics and may affect children submitted to limb amputation due to trauma, cancer or specific situations. Amputation may originate sensory changes, in the future related to phantom sensation or phantom limb pain ${ }^{16,17}$. According to study by Wilkins et al., painless phantom sensations affect $50 \%$ to $100 \%$ of children submitted to amputation surgery, and $7 \%$ to $20 \%$ of children with congenital limb defficiency ${ }^{17}$. According to the literature, these situations seem to resolve easily in chidren as compared to adults ${ }^{16,17}$.

CRPS may affect children and in general is characterized by NP. CRPS type II appears after peripheral nervous injury, while CRPS type I not always has an overt triggering cause, although clinical manifestations of both are simi$1 a r^{5}$. Pediatric CRPS has peak of incidence in early adolescence and, differently from adults, lower limbs are 6 to 8 times more affected as compared to upper limbs. CRPS diagnosis is based on clinical history and physical evaluation ${ }^{5}$.

Sickle cell disease is disseminated in several continents and corresponds to a group of genetic diseases with systemic manifestations characterized by chronic hemolysis and acute complications which may lead to risk of death and different levels of organic functions impairment. Sickle cell disease is autosomic recessive being characterized by the presence of hemoglobin $S$, which results in valine replacement by glutamic acid in position 6 of the beta chain. This aminoacid exchange determines deep changes in physicalchemical properties of hemoglobin when deoxygenated. Pain crisis is most common clinical sickle cell disease manifestation, and may appear as from six months of age and be recurrent along life, being major cause of first aid assistance and reason for hospitalizations ${ }^{18}$.

Acute pain management in the first aid unit is based on intravenous hydration and rapid start of intravenous analgesia with symptomatic and opioid analgesia. Interdisciplinary approach is recommended to treat chronic sickle cell disease pain, combining pharmacological and non-pharmacological interventions ${ }^{19-21}$.

It is estimated that NP is present in $20 \%$ to $40 \%$ of cancer adult patients ${ }^{22}$. There are multiple possible causes for NP in pediatric cancer patients. With regard to cancer-related neuropathic conditions and their treatment in the pediatric population, Bennett et al. have shown by a meta-analysis $39 \%$ prevalence of neuropathic mechanisms in cancer patients between 12 and 19 years of age ${ }^{22}$. Global cancer-related NP incidence is much lower in children, but phantom limb pain is more common in children suffering amputation due to cancer or perioperative chemotherapy. Peripheral neuropathy affects $50 \%$ to $90 \%$ of patients treated with platin compounds and almost half patients treated with vinca alkaloids ${ }^{10}$.

In a retrospective review involving 498 children receiving chemotherapy, 174 children have developed peripheral neuropathy related to the use of vincristine to treat acute lymphoblastic leukemia ${ }^{23}$. Several studies relate drugs such as taxanes, compounds with platin, vinca alkaloids and bortezomib to $\mathrm{NP}^{5,24}$. Chemotherapeutic agents such as vincristine, cisplatin and paclitaxel may induce NP which may persist for months or years after their use ${ }^{22}$.

Guidelines for NP evaluation and diagnosis were developed for adults and are frequently extrapolated to older children and adolescents. However, children have different metabolic profiles as compared to adults, so many therapeutic recommendations for adults cannot be safely applied to children ${ }^{5}$.

In 2012, the World Health Organization (WHO) has published guidelines to control persistent pain in children. The analgesic ladder until then used for children was modified to favor the two steps approach. The publication, called WHO Guidelines on the pharmacological treatment of persisting pain in children with medical illnesses ${ }^{25}$, defines "persistent pain" as long term pain and "medical illnesses" as specific situations where there is some tissue injury and a clear role for pharmacological treatment.

The objective of these guidelines is to supply evidence-based recommendations for pain management in children from zero to 10 years of age with persistent medical illnesses, including the use of opioid and non-opioid analgesics, in addition to adjuvant drugs for pain control. These guidelines may also be used for adolescents, since most collected and evaluated evidences come from studies with populations from zero to 18 years of age ${ }^{25}$. According to new guidelines, the two steps ladder gives preference to the use of lower strong opioid analgesic dose, rather than using weak opioids such as codeine and tramadol. These guidelines recommend paracetamol and ibuprofen as simple analgesics for mild pain ${ }^{8}$.

Althoug with very low quality of evidences, these WHO guidelines highlight that, to date, it is not possible to make recommendations in favor or against the use of tricyclic antidepressants, selective serotonin reuptake inhibitors, anticonvulsants, ketamine and lidocaine to treat NP in children. This recommendation is based on the lack of studies with good level of evidence in Pediatrics, although clinical experience in daily practice supports the use of such drugs.

Codeine has severe safety and efficacy problems related to genetic variability and biotransformation, which is true not only for the pediatric group. Codeine is a pro-drug, that is, it is converted into its active metabolite morphine by enzyme CYP2D6. The efficacy of a pro-drug depends on the amount of formed active metabolites. Variable expressions of enzymes involved in pro-drugs biotransformation may lead to differences in conversion rates and active metabolite plasma concentration in interindividual and interethnic way. In the fetus, CYP2D6 enzyme activity is absent or lower than $1 \%$ of adult values, and increases with growth. So, its analgesic 
effect is low or absent in neonates and younger children.

The percentage of weak metabolizing agents may vary in etnic groups from $1 \%$ to $30 \%$, which results in inefficacy in a large number of adults and children ${ }^{8,26}$. On the other hand, individuals rapidly metabolizing codeine in high proportion have variable risk of toxicity as a function of rapid and uncontrolled codeine conversion into morphine ${ }^{8,26}$.

Tramadol is a partial agonist with some action on NP and part of its analgesic effect is by serotonin and norepinephrine reuptake inhibition. In spite of favorable effects to control pain in childhood, further clinical trials are needed to confirm its efficacy and safety in this population ${ }^{8,26}$.

Morphine may also be used to treat $\mathrm{NP}^{27}$. Children with cancer and moderate to severe NP often need strong opioids. Adult studies showed that the traditional teaching that NP does not respond to opioid analgesics might not be true ${ }^{28}$. In children, NP may often be controlled with adjuvant analgesics to pain treatment, with no need to associate opioids. In adults, methadone may be useful to control NP due to its unique molecular characteristics. Although methadone and tramadol, in theory, may be beneficial for their complementary action to control nociceptive NP, there are no evidences supporting the fact that they are more effective than other opioids such as morphine, fentanyl, hydromorphone and oxycodone ${ }^{28}$.

Amitriptyline is a tricyclic antidepressant and first line drug to treat NP in children aged 6 years or above; however, it is not recommended for children below 6 years of age. Amitriptyline has effect on sleep, anxiety and depression, and its analgesic action basically results from norepinephrine and serotonin reuptake inhibition, but other pharmacological properties may contribute to analgesia, such as decreased sympathetic response, sodium channels block, anticholinergic activity and NMDA receptors antagonism ${ }^{5}$. Gabapentin is an anticonvulsant used in childhood which is also used as first line drug to treat NP, although not being recommended for children below 6 years of age. Gabapentin has a good safety and tolerance profile. Pregabalin is similar to gabapentin in terms of efficacy, but has a more favorable pharmacokinetic profile, being used off-label with good results in children ${ }^{5}$.

Other drugs, such as phenytoin, carbamazepine, valproate and clonazepam have reports of benefits to treat NP, but their use should be monitored due to potential secondary effects, especially metabolic disorders, liver toxicity and bone marrow suppression 5 .

In adults, 5\% lidocaine plaster has proven efficacy for localized NP of different etiologies, such as postherpetic neuralgia, diabetic neuropathy, postoperative neuropathic pain and low back pain with neuropathic componen $\mathrm{t}^{29}$. Literature reports describe the use of $5 \%$ lidocaine plaster in children with localized neuropathic pain, such as CRPS, sickle cell disease and pain from burn sequelae, but further studies are needed to establish the safety and efficacy of this drug for the pediatric population ${ }^{30}$.

\section{CONCLUSION}

NP treatment should be multimodal, including pharmacological treatment, rehabilitation and psychologic support. Rehabilitation, physiotherapy, occupational therapy and integrative therapies should be part of the integral treatment of children with NP and vary according to individual needs. Such strategies involve from physical therapies (massage, transcutaneous electrical nerve stimulation, comfortable position, touch), behavioral therapies (hypnosis, images, deep breathing), acupressure, acupuncture and aromatherapy, to the use of programs for smart-phones or tablet applications contributing to control pain. As with adults, the relationship between physical pain and psychoexistential suffering cannot be ignored in the pediatric population.

\section{REFERENCES}

1. Simons LE. Fear of pain in children and adolescents with neuropathic pain and complex regional pain syndrome. Pain. 2016;157(Suppl 1):S90-7.

2. Merskey H, Bogduk N. Classification of chronic pain: descriptions of chronic pain syndromes and definitions of pain terms. $2^{\text {nd }}$ ed. Seattle: IASP Press; 1994.

3. Treede RD, Jensen TS, Campbell JN, Cruccu G, Dostrovsky JO, Griffin JW, et al. Neuropathic pain: redefinition and a grading system for clinical and research purposes. Neurology. 2008;70(18): $1630-5$.

4. Brown SC, Taddio A, McGrath PA. Pharmacological Considerations in Infants and Children. In: Beaulieu P, Lussier D, Porreca F and Dickenson AH, (editors). Pharmacology of Pain. Seattle, IASP Press; 2010. 529-45p.

5. Toste S, Palhau LI Amorim R. Dor neuropática em idade pediátrica. Rev Soc Portuguesa Med Fís Reabil. 2015;27(1):22-9.

6. Walco GA, Dworkin RH, Krane EJ, Lebel AA, Treede R. Neuropathic pain in children: special considerations. Mayo Clin Proc. 2010;85:(Suppl):S33-41.

7. Pasin S, Avila F, de Cavatá T, Hunt A, Heldt E. Cross-cultural translation and adaptation to Brazilian Portuguese of the paediatric pain profile in children with severe cerebral palsy. J Pain Symptom Manage. 2013;45(1):120-8.

8. van Dijk A, McGrath P, Pickett W, Van Den Kerkhof EG. Pain prevalence in nine-to 13- year-old school children. Pain Res Manag. 2006;11(4):234-40.

9. Borsook D. Neurological diseases and pain. Brain. 2012;135(Pt2):320-44.

10. Howard RF, Walker SM, Mota PM, Fitzgerald M. The ontogeny of neuropathic pain: postnatal onset of mechanical allodynia in rat spared nerve injury (SNI) and chronic constriction injury (CCI) models. Pain. 2005;115(3):382-9.

11. Atherton DD, Taherzadeh O, Elliot D, Anand P. Age-dependent development of chronic neuropathic pain, allodynia and sensory recovery after upper limb nerve injury in children. J Hand Surg Eur. 2008;33(2):186-91.

12. Gaughan DM, Hughes MD, Seage GR 3rd, Selwyn PA, Carey VJ, Gortmaker SL, et al. The prevalence of pain in pediatric human immunodeficiency virus/acquired immunodeficiency syndrome as reported by participants in the Pediatric Late Outcomes Study (PACTG 219). Pediatrics. 2002;109(6):1144-52.

13. Hall GC, Carroll D, Parry D, McQuay HJ. Epidemiology and treatment of neuropathic pain: the UK primary care perspective. Pain. 2006;122(1-2):156-62

14. Blankenburg M, Kraemer N, Hirschfeld G, Krumova EK, Maier C, Hechler T, et al. Childhood diabetic neuropathy: functional impairment and non-invasive screening assessment. Diabet Med. 2012;29(11):1425-32.

15. Chou J, Chan CW, Chalkiadis GA. Post-thoracotomy pain in children and adolescence: a retrospective cross-sectional study. Pain Med. 2014;15(3):452-9.

16. Howard RF, Wiener S, Walker SM. Neuropathic pain in children. Arch Dis Child. 2014;99(1):84-9

17. Wilkins KL, McGrath PJ, Finley GA, Katz J. Phantom limb sensations and phantom limb pain in children and adolescent amputees. Pain. 1998;78(1):7-12.

18. Brasil. Ministério da Saúde. Secretaria de Atençáo à Saúde. Departamento de Atençáo Especializada. Doença falciforme: condutas básicas para tratamento / Ministério da Saúde, Secretaria de Atenção à Saúde, Departamento de Atenção Especializada. Brasília: Ministério da Saúde, 2012. 64 p.: il. (Série B. Textos Básicos de Saúde).

19. Steinberd MH. Sickle cell disease. Ann Intern Med. 2011;155:ITC3-1.

20. Dunlop RJ, Bennett KC. Pain management for sickle cell disease. Cochrane Database Syst Rev. 2006; (2):CD003350.

21. Ballas SK. Update on pain management in sickle cell disease. Hemoglobin. 2011;35(5-6):520-9.

22. Bennett MI, Rayment C, Hjermstad M, Aass N, Caraceni A, Kaasa S. Prevalence and aetiology of neuropathic pain in cancer patients: a systematic review. Pain. 2012;153(2):359-65

23. Anghelescu DL, Faughnan LG, Jeha S, Relling MV, Hinds PS, Sandlund JT, et al. Neuropathic pain during treatment for childhood acute lymphoblastic leukemia. Pediatr Blood Cancer. 2011;57(7):1147-53.

24. Park H. Chemotherapy induced peripheral neuropathic pain. Korean J Anesthesiol. 2014;67(1):4-7.

25. WHO guidelines on the pharmacological treatment of persisting pain in children with medical illnesses.WHO2012.Availablefrom:<URL:http://www.who.int/about/licensing/copyright_form/en/ index.html> [2014 aug 30].

26. Kraychete DC, Siqueira JT, Garcia JB e Grupo de Especialistas. Recomendaçóes para uso de opioide no Brasil: Parte II. Uso em crianças e idosos Rev Dor. 2014;15(1):65-9.

27. Eisenberg E, McNicol E, Carr DB. Opioids for neuropathic pain. Cochrane Database Syst Rev. 2006; 19:CD006146.

28. Friedrichsdorf SJ, Nugent AP. Management of neuropathic pain in children with cancer. Curr Opin Support Palliat Care. 2013;7(2):131-8.

29. Orellana Silva M, Yańez V, Hidalgo G, Valenzuela F, Saavedra R. 5\% lidocaine medicated plaster use in children with neuropathic pain from burn sequelae. Pain Med. 2013;14(3):422-9.

30. Buck ML. Use of lidocaine for analgesia in children and adolescents. Rev Ped Pharmacoth. 2013;19(12):1-10 